\title{
An Analysis of Fake Narratives on Social Media during 2019 Indonesian Presidential Election
}

\author{
VIENCE MUTIARA RUMATA \\ The Ministry of Communication and Informatics of the Republic of Indonesia
}

\author{
FAJAR KUALA NUGRAHA \\ Indonesia indicator, Indonesia
}

\begin{abstract}
Social media become a public sphere for political discussion in the world, with no exception in Indonesia. Social media have broadened public engagement but at the same time, it creates an inevitable effect of polarization particularly during the heightened political situation such as a presidential election. Studies found that there is a correlation between fake news and political polarization. In this paper, we identify and the pattern of fake narratives in Indonesia in three different time frames: (1) the Presidential campaign (23 September 2018 -13 April 2019); (2) the vote (14-17 April 2019); (3) the announcement (21-22 May 2019). We extracted and analyzed a data-set consisting of 806,742 Twitter messages, 143 Facebook posts, and 16,082 Instagram posts. We classified 43 fake narratives where Twitter was the most used platform to distribute fake narratives massively. The accusation of Muslim radical group behind Prabowo and Communist accusation towards the incumbent President Joko Widodo were the two top fake narratives during the campaign on Twitter and Facebook. The distribution of fake narratives to Prabowo was larger than that to Joko Widodo on those three platforms in this period. On the contrary, the distribution of fake narratives to Joko Widodo was significantly larger than that to Prabowo during the election and the announcement periods. The death threat of Joko Widodo was top fake narratives on these three platforms.
\end{abstract}

Keywords: Fake narratives, Indonesian presidential election, social media, political polarization, post.

\section{INTRODUCTION}

The existence of the internet has given a significant breakthrough for social and political contexts in Indonesia. Historically speaking, the internet has transformed from a medium to communicate to a medium to exercise power especially for a powerless group or part of the society. The Internet was initially emerged during the political transition in the late 1990s when a long-standing authoritarian President Soeharto came to end. It was an alternative medium for urban exclusive group members, with less interference from the authority, to communicate and exchange information. Then, it transformed into space for greater political participation. The information which is completely closed and confined must be changed so the public can access the information they need freely (Ahmadi, Rachmiatie, \& Nursyawal, 2019).

In the present day, social media give greater space for civil society to engage and participate in responding to a wide range of issues. Many social movements in Indonesia have initially been driven by the power of hashtags such as "\#KoinUntukPrita", "\#SaveKPK", "\#KamiTidakTakut" (Bohang, 2016). Studies confirm that social media are a room for value and belief creation (Bechmann \& Lomborg, 2012; Oh, Eom, \& Rao, 2015; Rodriguez, 2013), and these values and beliefs may even be incorporated in the social and cultural contexts of real-life (i.e. offline) (Lim, 2018). Therefore, any opinion that may be circulated among 
prominent social networking groups may change the way people think and believe. Lim (2013) argues that social media activism in Indonesia is more than just "slacktivism" or a random click and share; it is rather a transformative form of collective political activism with particular agendas. Democracy preserves people's rights to express their opinion and voices. As a platform, social media are able to preserve this right by allowing individuals to create and disseminate their own contents, including their opinion. Some scholars warn that social media may be counterproductive. Social media can be a double-edged sword which can disseminate good as well as bad information (Jalli, 2016). It is possible a person deliberately creates and disseminates fake narratives, misleading opinion, hate speech, and other similar contents on social media. Social media are effective tools to assist opinion leaders to disseminate political ideologies (Jalli, 2016). If social media fails to play its function as a public sphere, particularly when fake narratives, hate speech, and misleading information is circulated during the heightened political situation such the presidential election, then as Yerlikaya (2020) argues, social media and fake news pose threat for democracy.

Globally, the spread of fake narratives on social media during the heightened political situation is a common phenomenon. We have witnessed how Donald Trump won in the 2016 US Presidential Election by fake narratives and he, even, was awarded a 'Lie of the Year' by Politifact in 2015 because of his undeniable "mostly false, false or pants on fire" campaign statements (Holan \& Qiu, 2015). These fake narratives during US election were a symbol of 'informational moral panic' that targeted not a certain group but thickened wider concerns surrounding blurred lines between "traditional journalistic channels, click-driven news, the extension of mediated voices and the growing role of social media in news distribution" (Carlson, 2020).

The year of 2019 was the most hectic general election that ever occurred in Indonesia where more than 190 million of eligible voters voted for five candidates (the President and Vice President, the House of Representatives, the Regional House of Representatives in Province and Municipality level, as well as the Regional Representative Board). Hence, the 2019 general election was dubbed as the most complicated, exhaustive, but also a breathtaking election in the world (BBC Indonesia, 2019). During that year, the growing number of fake narratives or hoaxes circulating on social media was unbelievable. The Ministry of Communication and Informatics of the Republic of Indonesia (the $\mathrm{MCl}$ ) identified 486 fake news during April 2019, where 209 of them were fake political-related news (Maharani, 2019). In addition, the $\mathrm{MCl}$ identified 64 hoaxes after the presidential election, 18th to 20th of April 2019 (Bisnis.com, 2019). The spread of fake narratives, along with hate speech, had created a polarization between supporters of the incumbent President Joko Widodo (or known as Jokowi) and his most-fierce rival Prabowo.

Fake news is a critical phenomenon in Indonesia since most of the Indonesian netizens have lack of digital information literacy and critical thinking. A study found that educated groups such as students find it hard to differentiate between fake and valid news on social media (Syam \& Nurrahmi, 2020). The online news sites may play a critical role in educating their readers about fake news (Yuliarti, 2018). Nevertheless, most of the Indonesian online information consumers are tempted by exciting news titles and the way they judge whether the information considered fake or not by the presentation of the news that includes choices of words (Wijaya, 2019).

Previous studies about social media during the 2019 Indonesian presidential election highlight some findings such as social media role in lubricating satire political communication (Sujoko, 2020) and also constructing social identity and populist discourses (Santoso, Aziz, 
Pawito, Utari, \& Kartono, 2020). Nevertheless, the number studies that show fake narratives during this election is limited. Sosiawan and Wibowo (2019) analyze the content of hoaxes on social media from August 2018 to March 2019. Even so, it is not clear the process of data collection. To fill the gap, this paper shows emerging fake narratives during the 2019 Indonesian presidential election which uses big data approach for data collection and analysis. The primary data derived from three social networking platforms: Facebook, Twitter, and Instagram during three different time frames: (1) the Presidential Campaign (23 September 2018 -13 April 2019); (2) the Presidential Election (14-17 April 2019); (3) the Presidential Announcement (21-22 May 2019). There is a correlation between the use of Instagram and visiting interest followers (Ahmadi, \& Adzhani, 2019).

\section{LITERATURE REVIEW}

\section{Internet, Post-Truth and Democracy}

There are two ways scholars treat the internet in the context of political communication: 1 ) as a dependent variable (i.e. internet changes the nature of communication and relationship between government, media, citizens and other parties); and 2) as an independent variable (i.e. internet as a medium that formed by those parties' behaviours) (Sarah, Oates \& Gibson, 2006). The most interesting issue in this context is whether the internet is challenging democracy or not. The debate around this issue falls in two contradictive opinions which are first the internet provides more civil collaboration and deliberative democracy (discussion among the US scholars) and, second, the internet needs more public-constitutive elements in order to keep its virtual public sphere function (discussion among the European scholars) (Brandenburg, 2006). Nevertheless, one of the prominent Bradenburg's findings is the question of whether the internet naturally forms the deliberative environment or should be engineered. If the internet gives people information as much as they want as well as provides an inclusive and open environment for collaboration and discussions, the question remains whether these are preconditions for "ideal democracy". How if the internet has sort of defect that does not provide diverse information or medium for diverse opinions expression?

This Bradenburg's concern is relevant in today post-truth era, a popular term in 2016, when questions arise whether the internet exposes diverse opinion or traps people in the likeminded situation (Flaxman, Goel, \& Rao, 2016). The online discussion between "Leave" and "Remain" groups during Brexit in 2016, for example, showed clear two perspectives of the internet in the post-truth politics. First, it may provide political discussion forums with diverse voices. But, second, people who engage on those forums, in fact, create what is called "political homophily", a condition where shared and exclusive political meaning within a likeminded group that affecting on people's way of thinking, attitude, as well as interaction (Colleoni, Rozza, \& Arvidsson, 2014). Pariser (2011) raised concern about the inevitable 'filter bubble' trap where technology determines people's online preferences i.e., information. This condition poses threat to democracy when people voice is driven by an actor with hidden political agenda who created manipulative populist and political discourses that are circulated and echoed by technology (Santoso et al., 2020; Yerlikaya, 2020).

\section{Fake Narratives, Social Media, and Polarization}

There are several terminologies that describe fake narratives: hoaxes, fake news, misleading contents, and false information. The definition of "fake news" in this paper refers to false information intentionally produced to manipulate readers. Vojak (2017) divides fake news 
into two types: accidental and intentional. Accidental fake news may be caused by reckless people who just post news and had no idea that their posts would be viral in the next day. In contrast, intentional fake news is created deliberately by an actor or group of actors who also involves fake accounts in order to create chaos. Perhaps a question could rise with this division is who would have known of someone's intention once the fake news was viral on social media.

According to UNESCO, there is three types of 'information disorder': (1) Misinformation (false information shared by a person who believes is true and with no prior factchecking); (2) Dis-information (a deliberative lie and false information intentionally created and shared); and (3) Mal-information (true and reality-based information but shared to create chaos or harm a person, organization, or country) (UNESCO, 2018). Figure 1 shows disinformation lies in a sliced section between misinformation and mal-information. It may be interpreted that disinformation is not considered as 100 per cent false or intent to harm information. Below is a further explanation of some narratives that classified as these three types of information disorder:

- $\quad$ False context: the information that could be derived from a real event, but it may be reproduced, recirculated, and shared away from the real context. A photo, which may be taken years ago, went viral with a different meaning nowadays.

- Imposter content: To make false information in a convincing way, it is possible for someone to use mainstream media's logos, templates, or even fonts on the content.

- Manipulated content: contents that aim to deceive or manipulate people's opinion.

- $\quad$ Fabricated content: almost similar to manipulated content

It is hard to distinguish these narratives or contents. But the common thing between them is that the content is framed in such a way to convince others that it is true. Also, the production of disinformation could be intentionally aimed to misinform or to lead misperception. Rumata and Sastrosubroto (2018) argue that information in post-truth era is a form of net-attack 2.0 which is the reproduction of (could be) valid news that reframed in order to create false perception.

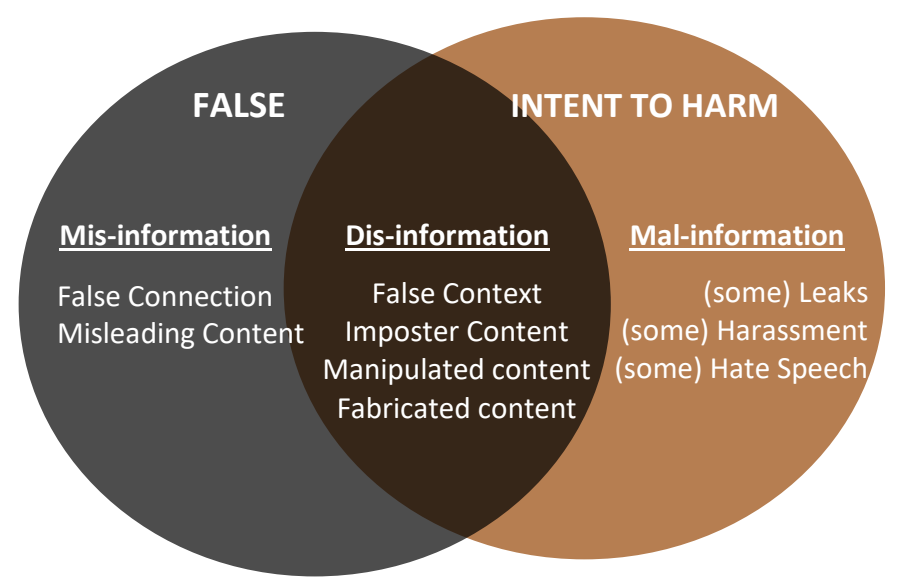

Figure 1: Information Disorder Types (UNESCO, 2018, p.46)

Post-truth is a phenomenon where people are losing trust and interest in facts (Lewandowsky, Ecker, \& Cook, 2017). The truth in post-truth era is never been discovered, but constructed by populism which lubricated by the media and technology (Salgado, 2018). 
Lies, baseless arguments, lack of evidence claims, misleading information which are repeatedly produced, reproduced, distributed and redistributed, to some extent, create a reality. People failed to think objectively and simply do fact-check of all the information that is received on social media. Being misinformed is something regular and acceptable as Lim (2013) argues as the typical of "the principles of the contemporary culture of consumption" that most of the social media users tend to share information because it has 'clickbait' title or misleading memes.

\section{Social Media and Polarization in Indonesian Democracy}

Social media have been a pivotal element in Indonesian politics at least for the last five years. Their role in creating a public sphere for freedom of expression may preserve the sustainability of the democratic system in the country. However, the practice of freedom of expression becomes paradox when this right has been misused by spreading fake narratives to smooth own hidden agendas.

Identity such as ethnic, religious, and ideology is the center of Indonesian political discourse. Religion, particularly, has been long-standing existing in Indonesian political history (Fuad, 2014). That is why religious fake narrative is proven to be an effective political campaign to drive people opinion and even worse to create the polarization. It may strongly emerge during Jakarta gubernatorial election back in 2017 where a Chinese-Christian candidate Basuki "Ahok" Tjahaja Purnama competed for head to head with his second-round rival an Arab-Muslim candidate Anies Baswedan. During this election, campaigns that attacked identities of a minority group in the society (i.e. Chinese and Christian) are legitimate and acceptable (Lim, 2017; Putra, 2016). Inevitably, fake news creates "us" and "them" in the form of "Pribumi" and "non-Pribumi".

This typical religious fake narrative campaign also occurred during the 2019 presidential election. The prominent Muslim radical figure and also Islamic Defender Front (Front Pembela Islam/ FPI) leader Habib Rizieq Shihab openly supported the four-time Presidential candidate Prabowo Subiakto (Lazuardi, 2019). Meanwhile, Prabowo's rival, the incumbent President Joko Widodo was accused of being insufficiently Muslim who promotes anti-Muslim and anti-Ulama movement (Republika online, 2019). The fake narratives that existed during this Presidential election are a reproduction of fake news that emerged during the 2014 Presidential election (i.e. Joko Widodo was accused as a communist) with the incumbent government as the main target (Sosiawan \& Wibowo, 2019). The fierce campaign strategies to counter fake narratives attacks was not solely executed by the candidates but also relentless buzzers of each supporter who work 24/7 either individually or in group team (Wareza, 2019). Satire political contents emerged and went viral on social media, as responses among millennials of thickened polarization that includes the fictive Presidential candidate Nurhadi-Aldo ("dildo") and Prabowo VS Jokowi-Epic Rap Battles of Presidency (Sujoko, 2020).

\section{METHODOLOGY}

This paper identifies and analyzes the fake narratives based on UNESCO's information disorder type on three social media platforms: Instagram, Twitter and Facebook. We use the Intelijen Persepsi Analisis (Intelligence Perceptive Analysis/ IPA) system developed by Indonesia Indicator Company, a strategic and big data company which is well known among central government and local government. The high-level process of the system consists of three parts, which are: 
1. The data sources that may include: Twitter (tweets, retweets, replies, and hashtags); Facebook (text captions, comments, photos, and videos); and Instagram (text captions and comments)

2. The data extraction and cleaning

3. The data analysis (data mining, statistics, GIS analysis, network analysis)

The second layer of this high-level process consists of three steps:

1. Crawler: a system for data reading or skimming to map out the data based on indexes on each of social media platforms.

2. Pipeline/ NLP (Natural Language Processing): a program to process, to analyze, to understand, and make sense of crawled data in a manner that is valuable. The output of this step is that data show some of the characteristics such as id account, text, sentiment, emotions, as well as demography.

3. Analytics: the final process where data analyzed and visualized in various ways on the dashboard.

The data are collected in three different time frames: 1 ) the Presidential Campaign (23 September 2018 - 13 April 2019); 2) the Presidential Vote (14-17 April 2019); 3) the Presidential Announcement (21-22 May 2019). These timelines show before, during, after the Presidential election and also ultimately during the announcement which we argue that the circulation of fake narratives during these time is critical. We exercise numbers of keywords to the system to extract the data.

We determine the keywords through observation and media literature. The "cebong", "kampret", "kaum bumi datar" or "bani micin" are popular terms that identify Joko Widodo or Prabowo's supporters. The keywords also include trending topics during the election such as "\#2019Ganti Presiden", \#2019TetapJokowi, and \#TNIpolisibukanpolitisi. Some of the labels previously appeared during Jakarta Gubernatorial Election in 2017 such as "bani koplak" (the idiot tribe) and "kaum bumi datar" (flat-earth people) which was labelled anti-Ahok supporters (Lim, 2017). Table 1 shows 82 keywords that had been exercised to collect the data.

Table 1: Keywords of fake narratives

\begin{tabular}{ccc}
\hline Refers to Joko Widodo & Refers to Prabowo & General \\
\hline Joko Widodo & Prabowo Subianto & Bunuh \\
Jokowi & Prabowo & Bakar \\
Kyai Hj. Ma'ruf Amin & Sandiaga Uno & Tembak \\
Ma'ruf & Sandi & Bangsat \\
Cebong & Kampret & Anjing \\
01 & 02 & Monyet \\
PKI & Khilafah & Babi \\
Komunis & HTI & Kristen \\
Cina & Hizbut Tahrir Indonesia & Islam \\
China & Sumbu Pendek & LGBT \\
Tiongkok & Prabohong & Ulama \\
Kafir & Sandiwara Uno & Dungu \\
Jokodok & Radikal & Waras \\
\hline
\end{tabular}




\begin{tabular}{|c|c|c|}
\hline \#2019GantiPresiden & Pelanggaran HAM & Orang Gila \\
\hline \#2019TetapJokowi & ISIS & Mukidi \\
\hline \#Jokowisekalilagi & Kaum Bumi Datar & \#INAElectionobserverSOS \\
\hline Anti Ulama & Bani Micin & Perang \\
\hline Partai Setan & Politik Genderuwo & Poling pilpres \\
\hline Rezim Dzalim & 2030 & Politik islam \\
\hline Jaenudin Nachiro & \#prabowobentengnkri & \#golput \\
\hline Kelas menengah ngehe & \#tutup01tusuk02 & \\
\hline Unicorn & \#prabowosanditakterbendung & \\
\hline IQ 200 Sekolam & Capres & \\
\hline \multicolumn{3}{|l|}{ Politik Sontoloyo } \\
\hline \multicolumn{3}{|l|}{ \#jokowitheerrorman } \\
\hline \multicolumn{3}{|l|}{ \#01caprespendustaabadi } \\
\hline \multicolumn{3}{|l|}{ \#TNIpolisibukanpolitisi } \\
\hline \multicolumn{3}{|l|}{ Diktator } \\
\hline \multicolumn{3}{|l|}{ \#Jokowilagi } \\
\hline \multicolumn{3}{|l|}{ \#JokowiAmin } \\
\hline \multicolumn{3}{|l|}{ Pemimpin Pendusta } \\
\hline \multicolumn{3}{|l|}{ \#Jokowi2periode } \\
\hline \multicolumn{3}{|l|}{ \#jokowiDILANjutkanlagi } \\
\hline \multicolumn{3}{|l|}{ Antek Asing } \\
\hline Penista Agama & & \\
\hline
\end{tabular}

\section{RESULTS AND DISCUSSION}

We manage to crawl at least 1.07 million fake narrative posts as well as tweets during these timelines. As seen in Table 2, Twitter is the most frequently used platform to distribute these kinds of contents which covers around 91.45 per cent. It is then followed by Facebook which is around 7.97 per cent and Instagram was the least one which contains 0.58 per cent. In the context of political and public engagement, Twitter probably is the platform that is mostly studied by scholars. The political discussion in this platform tends to be less uncivil and more deliberate although lack of empathy and respect (Jaidka, Zhou, \& Lelkes, 2019). Some of the Indonesian scholars were interested to study the sentiment analysis during the presidential election through Twitter (Ardiansyah, 2019; Nurhuda, Sihwi, \& Doewes, 2013). They may be able to show the sentiment analysis quantitatively, but they could not be able to show the details of the narrative.

Table 2: Tweeting and Posting Timeline

\begin{tabular}{ccccc}
\hline Time Frame & Twitter & Facebook & Instagram & Total \\
\hline 23rd Sept 2018 - 13th April 2019 & 826,914 & 143,665 & 16,082 & 986,661 \\
14 - 17 April 2019 & 73,932 & 10,389 & 1,672 & 85,993 \\
21 - 22 May 2019 & 4,649 & 1,422 & 213 & 6,284 \\
total & 905,495 & 155,476 & 17,967 & $1,078,938$ \\
\hline
\end{tabular}

Source: obtained from primary data 
We classify the data set in table 2 into specific issues based on outstanding narratives. The content classification also based on article number 28 of the ITE law. There are 43 classifications of issues during the presidential campaign; 12 classifications of issues during the presidential election; and, 6 classifications of issues during the presidential announcement. The frequency of fake narrative posts that attacked Prabowo is higher by numbers than that of Joko Widodo (Figure 2). However, the variance of fake narrative issues that attacked Prabowo is lesser than that of Joko Widodo (Figure 3).

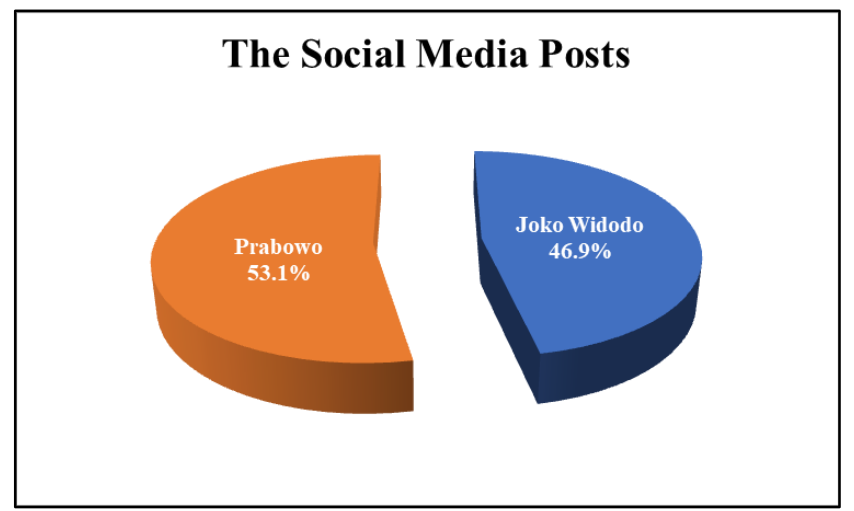

Figure 2: The frequency of fake narratives on three platforms

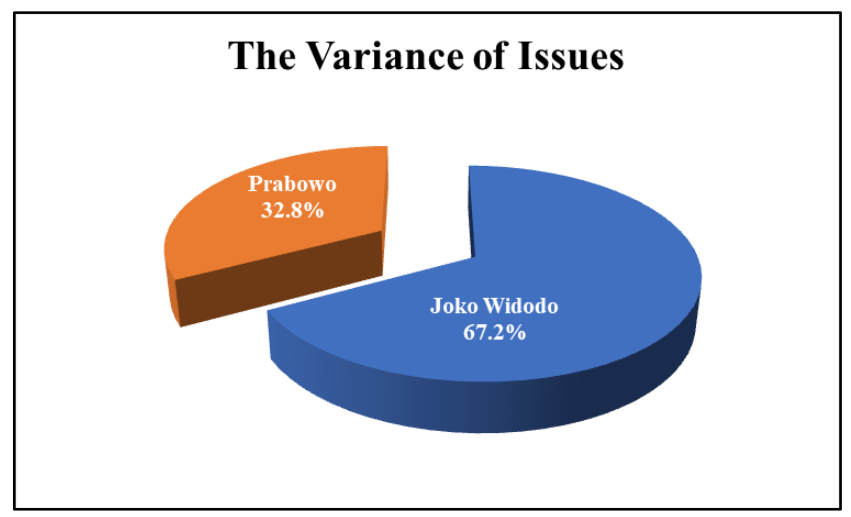

Figure 3: the variance of Fake Narratives on three platforms

In Table 3, there are 43 fake narrative themes during the presidential campaign. At least there were 559,446 posts (56.7 per cent) on these platforms that attacked Prabowo while there were 427,215 (43.3 per cent) posts that attacked Joko Widodo. Nevertheless, the variance of issues that attack Joko Widodo is higher than the ones to Prabowo which are 65.1 per cent to 34.9 per cent. Radicalism, communism, and pro-foreigner allegation are the top three issues during this period. Radicalism mostly attacked Prabowo while communist and pro-foreigner allegations attacked Joko Widodo.

Table 3: The fake narratives classifications during the Presidential Campaign

\begin{tabular}{|c|c|c|c|c|c|c|}
\hline \multirow[t]{2}{*}{ No } & \multirow{2}{*}{ Fake Narratives themes } & \multicolumn{5}{|c|}{$23^{\text {rd }}$ of Sept $2018-13^{\text {th }}$ of April 2019} \\
\hline & & Twitter & FB & IG & Total & Adversary \\
\hline 1 & $\begin{array}{l}\text { Radical Islamist groups support Prabowo's } \\
\text { Indonesian presidency }\end{array}$ & 130,123 & 30,515 & 1,171 & 156,682 & Prabowo \\
\hline 2 & Jokowi Communist Allegation & 133,317 & 21,096 & 2,269 & 161,809 & Joko Widodo \\
\hline 3 & Jokowi as a "pro-foreigner" & 92,811 & 10,781 & 1,751 & 105,343 & Joko Widodo \\
\hline 4 & Ratna Sarumpaet's false assault claim & 86,109 & 14,688 & 1,438 & 102,235 & Prabowo \\
\hline
\end{tabular}




\begin{tabular}{|c|c|c|c|c|c|c|}
\hline 5 & Russian political consultant behind Prabowo & 65,801 & 4,944 & 96 & 70,841 & Prabowo \\
\hline 6 & Prabowo violated human rights & 59,514 & 859 & 684 & 61,057 & Prabowo \\
\hline 7 & Prabowo's electability claims & 40,731 & 2,921 & 305 & 43,957 & Prabowo \\
\hline 8 & Prabowo Christmas Celebration & 25,406 & 5,640 & 778 & 31,824 & Prabowo \\
\hline 9 & Prabowo 's son LGBT status & 18,045 & 701 & 390 & 19,136 & Prabowo \\
\hline 10 & Jokowi hidden earpiece during debate & 15,183 & 55 & 97 & 15,335 & Joko Widodo \\
\hline 11 & Muslim "Ulama" leader Criminalization & 14,212 & 4,519 & 596 & 19,327 & Joko Widodo \\
\hline 12 & Jokowi supports LGBT & 13,915 & 1,676 & 282 & 15,873 & Joko Widodo \\
\hline 13 & $\begin{array}{l}\text { Central Java leaders' endorsement to } \\
\text { Jokowi }\end{array}$ & 11,194 & 2,286 & 160 & 13,640 & Joko Widodo \\
\hline 14 & Jokowi family's alleged corruption & 10,874 & 430 & 35 & 11,339 & Joko Widodo \\
\hline 15 & Uno family members support Jokowi & 9,682 & 646 & 377 & 10,705 & Prabowo \\
\hline 16 & Blood tubing polemic & 8,654 & 2,431 & 209 & 11,294 & Joko Widodo \\
\hline 17 & Jokowi meets Freeport CEO & 7,597 & 146 & 186 & 7,929 & Joko Widodo \\
\hline 18 & $\begin{array}{l}\text { Jokowi misuse the state facilities for } \\
\text { presidential campaign }\end{array}$ & 7,590 & 1,480 & 195 & 9,265 & Joko Widodo \\
\hline 19 & Tabloid Indonesia Barokah & 6,983 & 1,682 & 245 & 8,910 & Prabowo \\
\hline 20 & Scandal video of Sandiaga Uno & 6,584 & 159 & 49 & 6,792 & Prabowo \\
\hline 21 & "Pepes" Campaign in Karawang & 6,467 & 127 & 79 & 6,673 & Joko Widodo \\
\hline 22 & Mbah Maimoen pray & 6,350 & 4,958 & 2 & 11,310 & Joko Widodo \\
\hline 23 & Communist Allegation to Prabowo & 6,127 & 10,336 & 1,279 & 17,742 & Prabowo \\
\hline 24 & "Dana Desa" claim & 5,858 & 13 & 167 & 6,038 & Joko Widodo \\
\hline 25 & Prabowo's Chinese Descendant & 5,615 & 9,470 & 1,589 & 16,674 & Prabowo \\
\hline 26 & Indonesia's debt to Chinese Republic & 4,024 & 2,664 & 461 & 7,149 & Joko Widodo \\
\hline 27 & Seven ballot containers & 3,851 & 3,879 & 336 & 8,066 & Joko Widodo \\
\hline 28 & $\begin{array}{l}\text { The national budget for IMF-WB event in } \\
\text { Bali }\end{array}$ & 3,130 & 208 & 126 & 3,464 & Joko Widodo \\
\hline 29 & HTI Flag burning & 2,679 & 61 & 31 & 2,771 & Prabowo \\
\hline 30 & Luhut's envelope & 2,486 & 136 & 22 & 2,644 & Joko Widodo \\
\hline 31 & Hat Communist symbol during debate & 2,366 & 10 & 15 & 2,391 & Joko Widodo \\
\hline 32 & Jokowi bans Azan & 2,358 & 34 & 20 & 2,412 & Joko Widodo \\
\hline 33 & the precondition to move voting place & 2,155 & 38 & 92 & 2,285 & Joko Widodo \\
\hline 34 & $\begin{array}{l}\text { Ahok replaces Ma'ruf Amin as Vice } \\
\text { President candidate }\end{array}$ & 1,950 & 404 & 33 & 2,387 & Joko Widodo \\
\hline 35 & $\begin{array}{l}\text { Jakarta Gubenotarial election campaign } \\
\text { fund }\end{array}$ & 1,637 & 162 & 27 & 1,826 & Joko Widodo \\
\hline 36 & $\begin{array}{l}\text { the hacking of Uztad Abdul Somad's social } \\
\text { media account }\end{array}$ & 1,568 & 123 & 21 & 1,712 & Joko Widodo \\
\hline 37 & The Army vehicle for Prabowo campaign & 1,481 & 255 & 10 & 1,746 & Prabowo \\
\hline 38 & Hundreds Fake physical e-KTP & 880 & 127 & 13 & 1,020 & Joko Widodo \\
\hline 39 & Voting abroad & 671 & 506 & 185 & 1,362 & Joko Widodo \\
\hline 40 & Fake video about unemployment & 527 & 1 & 14 & 542 & Joko Widodo \\
\hline 41 & The criminalization of Prabowo supporters & 322 & 2,405 & 234 & 2,961 & Joko Widodo \\
\hline 42 & Najwa supports Prabowo-Sandi & 80 & 48 & 11 & 139 & Prabowo \\
\hline 43 & $\begin{array}{l}\text { Karni llyas was summoned to the } \\
\text { Presidential Palace }\end{array}$ & 7 & 45 & 2 & 54 & Joko Widodo \\
\hline
\end{tabular}

Source: obtained from primary data 
Table 4 shows fake narrative themes that emerged during the Presidential Election. Unlike during the Presidential campaign period, the frequency of fake narratives to Joko Widodo was significantly higher than that of Prabowo. There were 74,677 (86.8 \%) unfavourable social media posts for Joko Widodo while there were only 11,316 unfavourable (13.2 \%) posts for Prabowo.

The issue of Prabowo supporters' social media accounts hacking incident is the prominent issues, although personal religious of both candidates remain the target of the attack. Prabowo presidential campaign team spokesperson Ahmad Riza Patria accused that government, in this case, Joko Widodo administration, hacked Prabowo's supporter that included publicly known political allies such as Said Didu (CNN Indonesia, 2019). The discourse of "hoax factory" was constructed and aimed to question government's neutrality in politics while (at that time) President Joko Widodo ran for the election. It appeared not only on social media but also on mainstream media.

Table 4: The fake narratives classifications during the Presidential Vote

\begin{tabular}{|c|c|c|c|c|c|c|}
\hline \multirow[t]{2}{*}{ No } & \multirow{2}{*}{ Fake Narratives themes } & \multicolumn{5}{|c|}{$14^{\text {th }}-17^{\text {th }}$ of April 2019} \\
\hline & & Twitter & FB & IG & Total & Adversary \\
\hline 1 & $\begin{array}{l}\text { Prabowo supporters' account hacking } \\
\text { incident }\end{array}$ & 28,708 & 5,000 & 619 & 34,327 & Joko Widodo \\
\hline 2 & $\begin{array}{l}\text { LGBT community supports Jokowi- } \\
\text { Amin }\end{array}$ & 118 & 64 & 10 & 192 & Joko Widodo \\
\hline 3 & The chaotic voting abroad & 1,158 & 291 & 13 & 1,462 & Joko Widodo \\
\hline 4 & Prabowo supports Khilafah system & 2,051 & 921 & 73 & 3,045 & Prabowo \\
\hline 5 & $\begin{array}{l}\text { Religious blasphemer among Jokowi } \\
\text { supporters }\end{array}$ & 203 & 270 & 15 & 488 & Joko Widodo \\
\hline 6 & Jokowi Communist Allegation & 2,315 & 98 & 60 & 2,473 & Joko Widodo \\
\hline 7 & Jokowi personal religious attack & 6,538 & 42 & 219 & 6,799 & Joko Widodo \\
\hline 8 & Prabowo personal religious attack & 5,898 & 18 & 255 & 6,171 & Prabowo \\
\hline 9 & Allan Naim's journalist documents & 2,018 & 77 & 5 & 2,100 & Prabowo \\
\hline 10 & Prabowo-Sandi website hacking & 3,039 & 113 & 20 & 3,172 & Joko Widodo \\
\hline 11 & Sexy Killers documentary film & 4,594 & 34 & 12 & 4,640 & Joko Widodo \\
\hline 12 & Quick Count chaos & 17,292 & 3,461 & 371 & 21,124 & Joko Widodo \\
\hline
\end{tabular}

Source: obtained from primary data

Lastly, Table 5 shows fake narratives that emerged during the presidential announcement. The number of social media post that attacked Joko Widodo was higher, which were 4,297 posts (68.4 \%), than that to his rival Prabowo which were 1,987 posts (31.6 $\%)$. The death threat of Joko Widodo stands out among emerging fake narratives. Communism accusation to Joko Widodo remained to be existing. The interesting part during this period is the emerging of issue that is supposed to be favourable for Prabowo in which he is not the actor behind chaotic student-led protests in 1998 or what known as "Tragedi Semanggi". These findings may be contrary to a previous study conducted. Santoso and Nugroho (2019) analyze sentiment tendency on Facebook from 17 April 2019 until 22 May 2019. They found that both of the candidates obtained positive sentiment ( 85 per cent positive sentiment towards Joko Widodo and 76 per cent towards Prabowo). 
Table 5: The fake narratives classifications during the Presidential Announcement

\begin{tabular}{|c|c|c|c|c|c|c|}
\hline \multirow[t]{2}{*}{ No } & \multirow{2}{*}{ Fake Narratives themes } & \multicolumn{5}{|c|}{$21^{\text {st }}-22^{\text {nd }}$ of May 2019} \\
\hline & & Twitter & FB & IG & Total & Adversary \\
\hline 1 & Shooting rumour & 468 & 3 & 50 & 521 & Joko Widodo \\
\hline 2 & The death threat of Jokowi & 1,770 & 563 & 81 & 2,414 & Joko Widodo \\
\hline 3 & $\begin{array}{l}\text { Prabowo was not responsible for chaos } \\
\text { student-led protests in } 1998\end{array}$ & 1,496 & 264 & 26 & 1,786 & Prabowo \\
\hline 4 & Jokowi Communist Allegation & 679 & 385 & 37 & 1,101 & Joko Widodo \\
\hline 5 & $\begin{array}{l}\text { Radical Islamist groups support } \\
\text { Prabowo's Indonesian presidency }\end{array}$ & 58 & 138 & 5 & 201 & Prabowo \\
\hline 6 & "Police from China" shot protesters & 178 & 69 & 14 & 261 & Joko Widodo \\
\hline
\end{tabular}

In the post-truth era, people engage online with less critical thinking and more emotion appealing in the political context. The Candidate's policy agenda becomes less relevant information for political voters as Lim (2017) found it during Jakarta Gubernatorial election in 2017. The politic of identity during the 2019 Presidential election may not be as thick as the 2017 gubernatorial election. Both candidates are Muslim but have very different social and cultural backgrounds. Prabowo was born and raised in an upper-class family. His father was a high-profile economist Soemitro Djojohadikusumo and also was a minister in Soekarno's - the founding father and first Indonesian President - administration. Prabowo is well educated and used to be Soekarno's son in law (Viva online, 2019a). His rival Joko Widodo, on the other hand, represents most of Indonesians. He was born and raised in a typical Indonesian lower-class family. He worked hard to become a successful businessman. His political career began when he was elected as a Mayor of Solo in 2005 and reelected in 2010. He, then, successfully won Jakarta Governor Election in 2012 and elected as a President in 2014 (Viva online, 2019b). Both candidates have contrast political communication and campaign styles. Prabowo used populist campaign which defending marginalized commoners against the elite. Rhetorically, he framed government as corrupt, abusive of power and failure particularly to bring economic prosperity for Indonesian people (Ritonga \& Adela, 2020). His campaign-style tended overheated i.e., slammed podium at a campaign event. In contrast, Joko Widodo is a President of all Indonesians from Sabang (the most western city in North Sumatera) to Merauke (the most eastern city in West Papua). His "blusukan" approach (hearing from grass-root community) and a traditional protocol breaker are perceived as a humble and charmed President. Therefore, Joko Widodo was the toughest rival for Prabowo. It is to be noted that the 2019 election was the fourth time for Prabowo in attempting to become a President of the Republic of Indonesia.

What matters on political campaigns and discussions is the construction of common enemies or threats (Lim, 2017). Radicalism, communism, or unpopular political frames such as "pro-foreigner" and "pro-LGBT" are common labels to create common enemies in Indonesia. Radicalism discourse may be initially constructed since a prominent radical conservative Muslim group leader Habib Rizieq Shihab declared support to Prabowo and Vice President Candidate Sandiaga Uno. During Jakarta Gubernatorial Election, Rizieq Shihab extended his popularity and influence not only in Jakarta but also nationally. He initiated several mass rallies to sentence who they call as Islamic blasphemer Ahok during the 2017 Jakarta governor election. He is also Head of Supervisory Board of a National Movement of 
Indonesian Ulama Council Fatwa Guards (Gerakan Nasional Pengawal Fatwa MUI / GNPFMUI). This organization officially expanded into a National Movement of Ulama Fatwa Guards without MUI involvement (Sumandoyo, 2019). It is worth to note that MUI was established in 1975 to support the government in creating a peaceful and prosperous society based on Pancasila, the philosophy of Indonesian state (Hasyim, 2011).

The other common enemy frames during Presidential Election are Communism, proforeigner and LGBT. This finding confirms that Prabowo's effort to frame his rival Joko Widodo as "a secularist, communist, and agent of foreign interest" during the Presidential campaign (Mietzner \& Muhtadi, 2018). Prabowo openly warned that Indonesia, under Joko Widodo administration, is being too open for foreigners so that pose a threat to the local workers. This statement was made to respond to the new presidential regulation number 20 of 2018 which has been signed by president Joko Widodo (Llewellyn, 2019). This regulation authorized the company to hire foreign workers in order to increase foreign investment in the nation. A fake issue of "10 million Chinese mainland workers invade Indonesia" which appeared in 2016 (Turnbackhoax, 2016), reappeared and went viral on social media in 2019.

The Lesbian, Gay, Bisexual and Transgender (LGBT) issues mostly are controversial issues among conservative and traditional Indonesians. Not only within the whole Indonesian society, but the unpleasant frame of LGBT also exists among academicians particularly in the study of Media and Communication field (Rumata, 2019). The number of attacking violence toward the LGBT community particularly is increased since the early of 2010s (Ridwan \& Wu, 2018). A recent offensive movement against LGBT community occurred in 2017 where 141 people allegedly attacked a Jakarta-based gay club (NBC News, 2017). FPI notoriously invades LGBT community forums that include international LGB communion the 2010 International Lesbian, Gay, Bisexual, Transgender and Intersex Association (ILGA) conference in Surabaya and LGBT's the Q! Film Festival in Jakarta. Same-sex homophobia immanent exists both in personal, society and even national levels. In the society level, LGBT considered as a communicable virus like HIV that would be infected to young generations. Meanwhile, the recent judicial review of the Criminal Code (KUHP) has sparked protest from the LGBT community since it may legally harm individual freedom (Ridwan \& Wu, 2018). A Joko Widodo and Maruf Amin campaign logo allegedly similar to the LGBT movement logo - colourful stripes - went viral on social media.

Nevertheless, these fake narratives that are circulated on social media may jeopardize the Indonesian political and democratic system in the future. Some of the fake narratives that escalated on 2019 presidential election are continuing during Joko Widodo second-term administration. The terminology of "kadal gurun" (or popularly known as kadrun), which refers to right-wing extremists and fundamentalist group of people, create public debate both in social media and mainstream media. Most of the people who offended this label accused there is growing communist sympathizers who against Islam (detikcom, 2020).

Hampton, Shin, and Lu (2017) might find that social media particularly Facebook and Twitter have a direct and negative impact on daily political conversations both on- and offline social settings. However, this finding does not appear in the Indonesian political context. The polarization that occurred online may affect in offline setting (i.e. during 2017 Jakarta Gubernatorial Election conversation - Lim 2017) and may affect not only the personal social relationship but also greatly to democracy itself. 


\section{CONCLUSION}

This research study analyzes the pattern of fake narratives on three social media platforms: Instagram, Twitter and Facebook in three different time frames: 1) the Presidential Campaign (23 September 2018 -13 April 2019); 2) the Presidential Vote (14-17 April 2019); 3) the Presidential Announcement (21-22 May 2019).

This study also identifies more than 43 fake narrative themes during the 2019 Indonesian presidential election. The frequency of fake narratives that attacked Prabowo is slightly higher by numbers than that of Joko Widodo which is 53.1 per cent to 46.9 per cent. But in terms of variance, fake narratives that attacked Joko Widodo are more various than ones that attacked Prabowo which is 67.2 per cent to 32.8 per cent.

The fake narratives were more massively distributed on the Twitter platform than on Instagram and Facebook. The most frequent circulation of fake news occurred during the presidential campaign period since this period is longer than the presidential election and announcement. The fake narratives, in terms of frequency and variance, mostly attacked Prabowo than Joko Widodo in this period. Radicalism, communism, and pro-foreigner allegation are the top three fake narratives. Radicalism mostly attacked Prabowo while communist and pro-foreigner allegations attacked Joko Widodo.

During the presidential vote and announcement periods, fake narratives that attacked Joko Widodo is higher than that to Prabowo in terms of frequency and variance. The incident of Prabowo supporters' account by Joko Widodo's is the most prominent fake narrative than others during the Presidential Vote. While the death threat of Joko Widodo was the most prominent fake narrative during the Presidential Announcement period.

This study found that radicalism, communism, "pro-foreigner" and "pro-LGBT" are constructive issues created by both candidates in order to gain public supports. Not only that, some labels created and circulated on social media during the 2019 election are similar with the ones that emerged during the 2017 Jakarta Gubernatorial Election such as "cebong" and "kampret". We suggest future research regarding this topic would focus on the "master narrative" of fake narrative campaigns in the Presidential election which the limitation of this study. This master narrative plays a significant role to build meaning in a specific context and helps us to understand these fake narratives in the Presidential election history as well as in what way it relates to us. 


\section{ACKNOWLEDGEMENT}

We give our high gratitude to Indonesia Indicator which allowed us to analyze the data. This paper was presented on Annual Conference: Communication and Media and Culture Conference in 2019 by the first author.

\section{BIODATA}

Vience Mutiara Rumata is a junior researcher at the Ministry of Communication and Informatics of the Republic of Indonesia and Lecturer at Esa Unggul University, Indonesia. She completed her bachelor's degree in Management Communication at the University of Padjadjaran (Indonesia) in 2006. She was awarded an Australia Awards Scholarship in 2013 and completed her master's degree in global media communication at the University of Melbourne (Australia) in 2015. Her subject of research field is media and communication but not limited to the following areas: internet governance, digital behaviour, societal impact of ICT, and digital culture. Email: vien001@kominfo.go.id

Fajar Kuala Nugraha is a leader of media analyst in the Central Government Division at the Indonesia Indicator, a strategic intelligence company in Indonesia. He has been working as media and social media analyst for four years. His most research of area relates to general as well as local elections and public opinion towards specific central and local governmental institutions. Also, he is an analyst supervisor for Bawaslu (Election Supervisory Agency), an expert for Banyuwangi local government, and a media analyst for TNI AD (an Indonesian Army).Email: kualanugraha@gmail.com 


\section{REFERENCES}

Ahmadi, D., \& Adzhani, A. V. (2019). The use of Instagram with visiting interest: The correlation between the use of @littlecollins.bdg Instagram with visiting interest. Journal of Physics: Conference Series, 1375(1), 1-6. https://doi.org/10.1088/17426596/1375/1/012055

Ahmadi, D., Rachmiatie, A., \& Nursyawal. (2019). Public participation model for public information disclosure. Jurnal Komunikasi: Malaysian Journal of Communication, 35(4), 305-321. https://doi.org/10.17576/JKMJC-2019-3504-19

Ardiansyah, R. (2019). Analisis sentimen calon presiden dan wakil presiden periode 2019-2024 pasca debat pilpres di Twitter. ScientiCO: Computer Science and Informatics Journal, 2(1), 21-28.

BBC Indonesia. (2019). Pemilu 2019: Pemungutan suara Indonesia paling "rumit" dan "menakjubkan" di dunia. Retrieved on January 22, 2020, from https://www.bbc.com/indonesia/indonesia-47879833

Bechmann, A., \& Lomborg, S. (2012). Mapping actor roles in social media: Different perspectives on value creation in theories of user participation. New Media \& Society, 15(5), 765-781.

Bisnis.com. (2019). 3 hari usai pemilu, Kementerian Kominfo temukan 64 hoax. Retrieved on October 28, 2019, from https://bisnis.tempo.co/read/1197714/3-hari-usai-pemilukementerian-kominfo-temukan-64-hoax/full\&view=ok

Bohang, F. K. (2016). Dari \#KoinUntukPrita hingga @Jokowi, 10 momen ikonik Twitter di Indonesia. Retrieved on October 28, 2019, from https://tekno.kompas.com/read/2016/03/26/12110007/Dari.KoinUntukPrita.Hingga. Jokowi.10.Momen.Ikonik.Twitter.di.Indonesia?page=all

Brandenburg, H. (2006). Pathologies of the virtual public sphere. In S. Oates, D. Owen, \& R. K. Gibson (Eds.), The internet and politics: Citizens, voters, and activitsts (pp. 185-198). Oxon: Routledge.

Carlson, M. (2020). Fake news as an informational moral panic: The symbolic deviancy of social media during the 2016 US presidential election. Information Communication and Society, 23(3), 374-388. https://doi.org/10.1080/1369118X.2018.1505934

CNN Indonesia. (2019). BPN tuding pemerintah biang hoaks dan retas akun pendukung. Retrieved on November 4, 2019, from https://www.cnnindonesia.com/nasional/20190414233517-32-386357/bpn-tudingpemerintah-biang-hoaks-dan-retas-akun-pendukung

Colleoni, E., Rozza, A., \& Arvidsson, A. (2014). Echo chamber or public sphere? Predicting political orientation and measuring political homophily in Twitter using big data. Journal of Communication, 64(2014), 317-332.

detikcom. (2020). Debat istilah "Kadrun", bikinan PKI atau semata "kadal gurun". Retrieved on September 28, 2020, from https://news.detik.com/berita/d-5048771/debatistilah-kadrun-bikinan-pki-atau-semata-kadal-gurun

Flaxman, S. ., Goel, S. ., \& Rao, J. M. (2016). Filter bubbles, echo chambers, and online news consumption. Public Opinion Quarterly, 80(2016), 298-320.

Fuad, A. B. B. (2014). Political identity and election in Indonesian democracy: A case study in Karang Pandan Village - Malang, Indonesia. The 4th International Conference on Sustainable Future for Human Security SUSTAIN 2013 (pp. 477-485). https://doi.org/https://doi.org/10.1016/j.proenv.2014.03.060 
Hampton, K. N., Shin, I., \& Lu, W. (2017). Social media and political discussion: When online presence silences offline conversation. Information Communication and Society, 20(7), 1090-1107. https://doi.org/10.1080/1369118X.2016.1218526

Hasyim, S. (2011). The Council of Indonesian Ulama (Majelis Ulama Indonesia, MUI) and religious freedom. Irasec's Discussion Papers, 12(2011). Retrieved from http://www.irasec.com/documents/fichiers/47.pdf

Holan, A. D., \& Qiu, L. (2015). 2015 lie of the year: The campaign misstatements of Donald Trump. Retrieved on September 26, 2020, from https://www.politifact.com/article/2015/dec/21/2015-lie-year-donald-trumpcampaign-misstatements/

Jaidka, K., Zhou, A., \& Lelkes, Y. (2019). Brevity is the soul of Twitter: The constraint affordance and political discussion. Journal of Communication, 69(2019), 345-372.

Jalli, N. B. (2016). The effectiveness of social media in assisting opinion leaders to disseminate political ideologies in developing countries: The case of Malaysia. Jurnal Komunikasi: Malaysian Journal of Communication, 32(1), 233-260. https://doi.org/10.17576/jkmjc-2016-3201-26

Lazuardi, G. (2019). 10 alasan Rizieq Shihab dukung Prabowo-Sandi, di antaranya menentang kriminalisasi terhadap ulama. Retrieved on October 29, 2019, from https://www.tribunnews.com/pilpres-2019/2019/04/07/10-alasan-rizieq-shihabdukung-prabowo-sandi

Lewandowsky, S., Ecker, U. K. H., \& Cook, J. (2017). Beyond misinformation: Understanding and coping with the "post-truth" era. Journal of Applied Research in Memory and Cognition, 6(4), 353-369. https://doi.org/10.1016/j.jarmac.2017.07.008

Lim, M. (2018). Dis/Connection: The co-evolution of sociocultural and material infrastructures of the internet in Indonesia. Indonesia, 105, 155-172. https://doi.org/10.1353/ind.2018.0006

Lim, M. (2013). Many clicks but little sticks: Social media activism in Indonesia. Journal of Contemporary Asia, 43(4), 636-657.

Lim, M. (2017). Freedom to hate: Social media, algorithmic enclaves, and the rise of tribal nationalism in Indonesia. Critical Asian Studies, 49(3), 1-17. https://doi.org/10.1080/14672715.2017.1341188

Llewellyn, A. (2019). Foreign workers under fire ahead of Indonesian presidential election. Retrieved on November 22, 2019, from https://thediplomat.com/2018/05/foreignworkers-under-fire-ahead-of-indonesian-presidential-election/

Maharani, T. (2019). Kominfo Identifikasi 486 hoax sepanjang April 2019, 209 terkait politik. Retrieved on October 28, 2019, from https://news.detik.com/berita/d4532182/kominfo-identifikasi-486-hoax-sepanjang-april-2019-209-terkait-politik

Mietzner, M., \& Muhtadi, B. (2018). Explaining the 2016 Islamist mobilisation in Indonesia: Religious intolerance, militant groups and the politics of accommodation. Asian Studies Review, 42(3), 479-497.

NBC News. (2017). Jakarta police arrest 141 in raid on Indonesia gay club. Retrieved on November 22, 2019, from https://www.nbcnews.com/feature/nbc-out/indonesianpolice-detain-141-men-gay-club-raid-n763006

Nurhuda, F., Sihwi, S. W., \& Doewes, A. (2013). Analisis sentimen masyarakat terhadap calon presiden Indonesia 2014 berdasarkan opini dari Twitter menggunakan metode Naive Bayes classifier. Jurnal Teknologi \& Informasi ITSmart, 2(2), 35-42. https://doi.org/10.20961/its.v2i2.630 
Oates, S., \& Gibson, R. K. (2006). The internet, civil society and democracy. In S. Oates, D. Owen, \& R. K. Gibson (Eds.), The internet and politics: Citizens, voters, and activists. (pp. 1-16). New York: Routledge.

Oh, O., Eom, C., \& Rao, H. (2015). Research note-role of social media in social change: An analysis of collective sense-making during the 2011 Egypt revolution. Information Systems Research, 26(1), 210-223.

Pariser, E. (2011). The filter bubble. New York: The Penguin Press.

United Nations Educational, Scientific and Cultural Organization (UNESCO). (2018) Journalism, "fake news" \& disinformation: Handbook for journalism education and training. France: Author.

Putra, I. E. (2016). Representations and discourse about religion and Chinese descendants in 2012 Jakarta's election. The Qualitative Report, 21(10). Retrieved from http://bit.ly/2po8Qyd

Republika online. (2019). Islam kafah ala Jokowi. Retrieved on October 29, 2019, from https://nasional.republika.co.id/berita/nasional/news-analysis/po6zt9409/islamkafah-emala-emjokowi

Ridwan, R., \& Wu, J. (2018). 'Being young and LGBT, what could be worse?' Analysis of youth LGBT activism in Indonesia: challenges and ways forward. Gender \& Development, 26(1), 121-138.

Ritonga, A. D., \& Adela, F. P. (2020). Mencermati populisme Prabowo sebagai bentuk gaya diskursif saat kampanye politik pada pemilihan presiden 2019. POLITEIA: Jurnal IImu Politik, 12(1), 1-13. https://doi.org/10.32734/politeia.v12i1.3170

Rodriguez, S. (2013). Making sense of social change: Observing collective action in networked cultures. Sociology Compass, 7(12), 1053-1064.

Rumata, V. M., \& Sastrosubroto, A. S. (2018). Net-attack 2.0: Digital post-truth and its regulatory challenges in Indonesia. Advances in Social Science, Education and Humanities Research, 165, 116-120.

Rumata, V. M. (2019). Lesbi, gay, biseksual, dan transgender dalam bingkai kajian media dan komunikasi: Sebuah kajian literatur sistematis. Jurnal Diakom, 2(2), 168-177.

Salgado, S. (2018). Online media impact on politics. Views on post-truth politics and postmodernism. International Journal of Media \& Cultural Politics, 14(3), 317-331. https://doi.org/10.1386/macp.14.3.317_1

Santoso, D. H., Aziz, J., Pawito, Utari, P., \& Kartono, D. (2020). Populism in new media: The online presidential campaign discourse in Indonesia. GEMA Online ${ }^{\circledR}$ Journal of Language Studies, 20(2), 115-133. https://doi.org/http://doi.org/10.17576/gema2020-2002-07

Santoso, E. B., \& Nugroho, A. (2019). Analisis sentimen calon presiden Indonesia 2019 berdasarkan komentar publik di Facebook. Jurnal Eksplora Informatika, 9(1), 60-69. https://doi.org/10.30864/eksplora.v9i1.254

Sosiawan, E. A., \& Wibowo, R. (2019). Kontestasi berita hoax pemilu presiden tahun 2019 di media daring dan media sosial. Jurnal IImu Komunikasi, 17(2), 133-142.

Sujoko, A. (2020). Satirical political communication 2019 Indonesia's presidential election on social media. Informasi, 50(1), 15-29. http://doi.org/10.21831/informasi.v50i1.30174

Sumandoyo, A. (2019). Agenda politik di balik GNPF ulama \& alumni 212. Retrieved on November 4, 2019, from https://tirto.id/agenda-politik-di-balik-gnpf-ulama-alumni212-cJKe 
Syam, H. M., \& Nurrahmi, F. (2020). I don't know if it is fake or real news: How little Indonesian university students understand social media literacy. Jurnal Komunikasi: Malaysian Journal of Communication, 36(2), 92-105. https://doi.org/10.17576/JKMJC-20203602-06

Turnbackhoax. (2016). [HOAX] 10 juta tenaga kerja Tiongkok masuk ke Indonesia. Retrieved on October 28, 2018, from https://turnbackhoax.id/2016/12/08/hoax-10-juta-tenagakerja-tiongkok-masuk-ke-indonesia/

Vojak, B. (2017). Fake news: The commoditization of internet speech. California Western International Law Journal, 48.

Wareza, M. (2019). KSP jadi kakak pembina buzzer Jokowi? Ini riset tarifnya. Retrieved on October 29, 2019, from https://www.cnbcindonesia.com/market/2019100519335217-104718/ksp-jadi-kakak-pembina-buzzer-jokowi-ini-riset-tarifnya

Wijaya, B. S. (2019). Dancing with the impropriety of media: How Indonesian consumers think and behave towards the unethical and illogical online news. Jurnal Komunikasi: Malaysian Journal of Communication, 35(1), 187-205. https://doi.org/10.17576/JKMJC-2019-3501-13

Yerlikaya, T. (2020). Social media and fake news in the post-truth era: The manipulation of politics in the election process. Insight Turkey, 22(2), 177-196. https://doi.org/10.25253/99.2020222.11

Yuliarti, M. S. (2018). Hoax and new media: Content analysis of news about hoax in www.viva.co.id. Jurnal Komunikasi: Malaysian Journal of Communication, 34(3), 258270. https://doi.org/10.17576/JKMJC-2018-3403-15 